\title{
Структурные и оптические свойства многослойных периодических структур с псевдоморфными слоями GeSiSn
}

\author{
В.А. Тимофеев ${ }^{1}$, В.И. Машанов ${ }^{1}$, А.И. Никифоров ${ }^{1}$, А.А. Блошкин ${ }^{1}$, И.Д. Лошкарев ${ }^{1}$, И.В. Скворцов ${ }^{1}$, \\ Д.В. Коляда ${ }^{2}$, Д.Д. Фирсов², О.С. Комков ${ }^{2}$ \\ ${ }^{1}$ Институт физики полупроводников им. А.В. Ржанова, Новосибирск, \\ 630090, пр. ак. Лаврентьева 13 \\ ${ }^{2}$ СПб ГЭТУ «ЛЭТИ», Санкт-Петербург, 197376, Профессора Попова 29 \\ тел:+7 (383) 330-7934, эл.nочта: Vyacheslav.t@isp.nsc.ru
}

DOI $10.34077 /$ RCSP2021-78

Добавляя $\mathrm{Sn}$ в матрицу $\mathrm{GeSi}$, можно проводить зонный инжиниринг исходного материала. Увеличение содержания олова приводит к уменьшению ширины запрещенной зоны. Материалы на основе соединений GeSiSn демонстрируют фотоотклик в инфракрасном диапазоне от 1.55 мкм вплоть до 4 мкм $[1,2]$. Фотоотклик основан на межзонных переходах носителей заряда. Основным нашим преимуществом перед другими работами, использующими материалы IV группы, является применение упругонапряженных слоев GeSiSn, которые не содержат дислокации.

В работе изучен рост многослойных периодических структур и сверхрешеток, включающих упругонапряженные слои GeSiSn с содержанием олова от 0 до 18 \%. Установлена кинетическая диаграмма роста слоев GeSiSn с высоким содержанием Sn в диапазоне температур $100-300{ }^{\circ} \mathrm{C}$. На основе кинетических диаграмм роста пленок GeSiSn выбиралась область толщин, соответствующая псевдоморфному состоянию. В процессе роста кремния поверх слоев GeSiSn наблюдались различные сверхструктуры в зависимости от содержания олова в слое твердого раствора и температуры осаждения кремния в многослойной периодической структуре. Эти сверхструктуры соответствуют определенному покрытию олова. Методом рентгеновской дифрактометрии изучены напряженное состояние, состав, качество гетерограниц и термическая стабильность многослойных периодических структур. Показано, что отжиг образцов вплоть до $550{ }^{\circ} \mathrm{C}$ не приводит к заметному смещению нулевого сателлита, определяющего средний состав слоя твердого раствора. Изучение оптических свойств полученных наноструктур проводилось методами низкотемпературной фотолюминесценции (ФЛ). Исследовано влияние температуры, а также мощности и длины волны накачки на спектры ФЛ. На рисунке продемонстрировано увеличение интенсивности инфракрасного излучения наноструктуры при изменении числа периодов сверхрешётки $\mathrm{Ge}_{0.3} \mathrm{Si}_{0.63} \mathrm{Sn}_{0.07} / \mathrm{Si}$ с 10 до 20 периодов. Интегральная

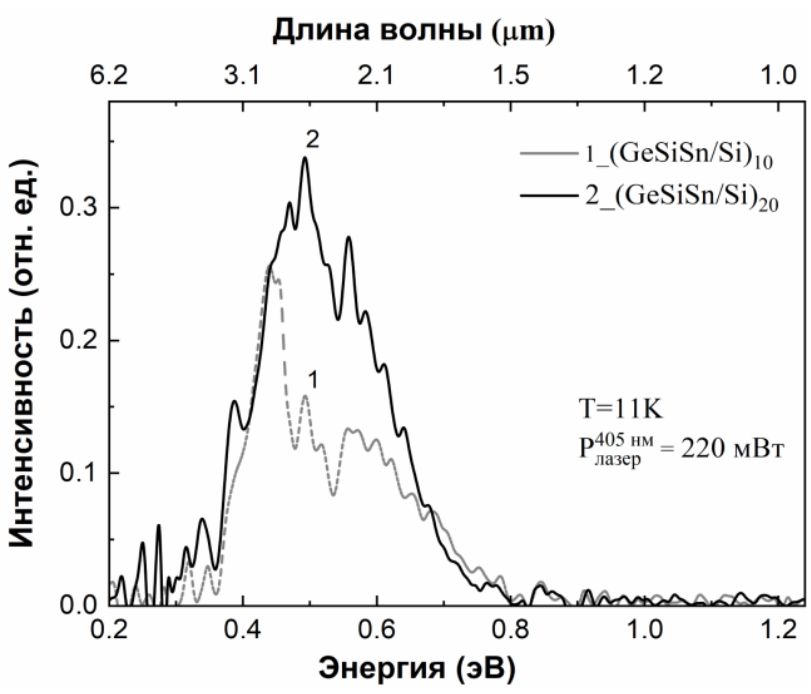
интенсивность ФЛ растет более чем в 1.5 раза. Полученный сигнал обладает высокой температурной стабильностью и однородностью по площади структуры. На основе измерений фототока диодных структур со сверхрешетками $\mathrm{Ge}_{0.3} \mathrm{Si}_{0.7-\mathrm{y}} \mathrm{Sn}_{\mathrm{y}} / \mathrm{Si}$ в активной области была экспериментально определена красная граница межзонной фотопроводимости в зависимости от содержания олова в квантовых ямах. В диапазоне составов олова от 3.5 до $9 \%$ наблюдается линейная зависимость энергии красной границы фотопроводимости от состава. С увеличением содержания $\mathrm{Sn}$ до 12.5 \% зависимость пороговой энергии фотопроводимости от состава отклоняется от линейного закона. Обнаружено, что в структурах $\mathrm{Ge}_{0.3} \mathrm{Si}_{0.7-\mathrm{y}} \mathrm{Sn}_{\mathrm{y}} / \mathrm{Si}$ с псевдоморфными слоями $\mathrm{Ge}_{0.3} \mathrm{Si}_{0.7-\mathrm{y}} \mathrm{Sn}_{\mathrm{y}}$ с содержанием $\mathrm{Sn} 12.5$ \% наблюдается межзонная фотопроводимость вплоть до длины волны 2 мкм.

Работа была поддержана Российским научным фондом (РНФ), грант № 20-79-10092.

\section{Лumepamypa}

[1] S. Assali et al., // Applied Physics Letters, 2018. V. 112. P. 25903.

[2] X. Wang et al., // Frontiers in Physics, 2019. V. 7, P. 134. 